\title{
Enhancing the Electrical Conductivity of Aromatic Polyamids Via Insertion of Azo Group in the Main Chain
}

\author{
Asaad F. Khattab \\ Shamil M. Hammo \\ Department of Chemistry \\ College of Science \\ Mosul University
}

(Received 3/ 2/ 2010 ; Accepted 15/3/2010 )

\begin{abstract}
New aromatic polyamides have been prepared through copolymerization of a tetrazo molecule with terephthalic acid.

Electrical conductivity measurements of the pure polymers show an enhancement of the electrical conductivity with increasing the azo moieties in the backbone of the polymer. The results can be rationalized by the effect of the dipole moment of the azo group.

Doping effect with iodine was also studied. The conductivity of the investigated polymers was increased by many order of magnitude through the doping process.

The study proved that the alignment of the dipole moment of the groups along the polymeric chain will give another reason for enhancing the electrical conductivity of the polymers .
\end{abstract}

Keywords: Azo polymer, electrical conductivity, polyamide.

\section{زباة التوصيلية الكهرائية للبولي ألميد الاروماتي عنطرق إنخلمجموعة الازو ضصن لالسلة الرئيسية}

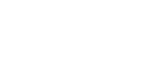

حضرت بولي لميدات جدية من خلل البلمرة المشتركة لجزيئت التترا آزومع حلمض التريفثاليك ،

أثبتت قيلست التوصيلية الكهربائية للبوليمرات الجيدة بلن التوصيلية الكهربائية تزداد مع زيادة نسبة وج ـود مجموعة الازو ضمن اللسلة الرئيسية للبوليمر، وقد عزى ذلك لتأثير عزم شنائي الثط حب لمجموء ـة الازو الممتد علىطول للسلسلة.

درس أيضا تأثير الثشويب بولسطة اليود، حيث لوهظ زياة في التوصيلية الكهربائية للبوليمرات بع ــة

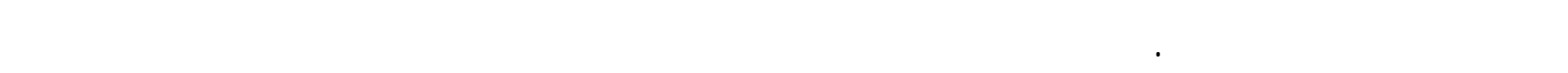

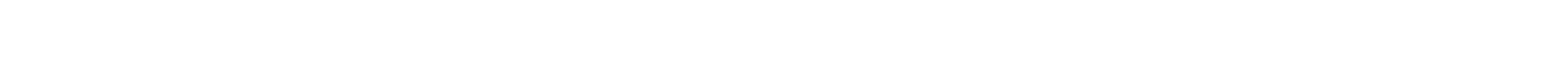
المعروفة . 